Article

\title{
External Costs as Driving Forces of Land Use Changes
}

\section{Dirk Loehr}

University of Applied Sciences, Trier, Environmental Campus Birkenfeld, P.O. Box 1380, D-55761 Birkenfeld, Germany; E-Mail: d.loehr@umwelt-campus.de; Tel.: +49-6782-1324; Fax: +49-6782-1437.

Received: 23 March 2010; in revised form: 7 April 2010 / Accepted: 15 April 2010 /

Published: 19 April 2010

\begin{abstract}
Land conversion is often not carried out in a sustainable way. The loss of arable land and biodiversity, concern about food security and rising costs of infrastructure due to urban sprawl are just some of the problems under discussion. This paper compares Germany, China and Cambodia. The article points out that, despite huge differences in institutions and governance, unsustainable land use changes mostly have some patterns in common: The beneficiaries of land conversion are often well-organized actors, whereas the costs of land conversion are often shifted to poorly organized groups and to society as a whole. A sustainable land use policy has to look for a better coupling of benefits and costs of land use changes. In order to achieve this goal, the article suggests completing the planning law with a suitable economic framework.
\end{abstract}

Keywords: land use changes; planning; property tax; financial equalization scheme

\section{Introduction}

Land use changes have many faces, and these changes are often not carried out in a sustainable way. In this article, we will focus on two types of land use, using three countries for illustration. Land conversion from agricultural to construction land, using Germany and China as examples; small-size farming into large-scale agro-industrial production, illustrated by the case of Cambodia.

Looking at the first type of land conversion, the different countries have different issues of concern. In Germany, the issues discussed include the loss of biodiversity, rising infrastructure costs or the problem of provision for elderly people or single parents in remote areas. The German government wants to reduce daily conversion to 30 hectares per day by 2020 [1]. Research programs such as 
"REFINA", and several think tanks are to provide concepts to stop the "consumption of land" [2]. To date, these efforts have essentially been unsuccessful.

Although China's total land mass is larger than that of the United States (9.6 and 9.4 million square kilometers, respectively), the area suitable for human inhabitancy is very limited and concentrated in the eastern provinces. This kind of land only covers $48 \%$ of the nation's territory, but it represents nearly $86 \%$ of the total farmland and nearly $94 \%$ of the population of 1.3 billion. In the eastern part of China, settlements historically emerged on high-quality farmland, which is now affected by conversion processes driven by population growth and the economic upswing. On the other hand, China has to feed $20 \%$ of the world's population with only $7 \%$ of the world's farmland [3]. Thus, the loss of farmland is also considered a problem. The Chinese government is worrying mainly about food security and has fixed a minimum of 120.0 million hectares (1.80 billion $\mathrm{mu}, 15 \mathrm{mu}=1$ hectare) as a "red line" [4].

In Cambodia, scarcely controlled conversion of farmland is also a problem. Particularly the suburban regions of large cities are affected. For example, since 2005 an estimated $40 \mathrm{~km}^{2}$ of rice fields along the National Road No. 4 in Kampong Speu province (near Phnom Penh) have been bought by developers, mostly from smallholders. The developers were surfing on a bubble of rapidly rising real estate prices in Cambodia during this time (2005-mid 2008). The rice fields were filled with sand and thus converted into construction land, without taking any land use plan into consideration. Nonetheless, huge parts of this "wild" conversion have subsequently been legalized. A proper database describing the dimensions of such aberrations does not exist. However, experts believe that impacts on food security are possible in the long run. Land use planning is in its infancy and is not in a position to create barriers to such processes [5]. However, we are looking at Cambodia in particular because of another type of land conversion: the conversion from small-size farming into large-scale agro-industrial production. In Cambodia, what are known as "Economic Land Concessions" ("ELCs", Art. 49 Cambodian Land Law 2001, Sub-Decree No. 146, 2005) are given to agro-industrial companies for large-size agro-industrial plantations or other economic exploitation [6]. Most of these companies are export-oriented. Although ELCs are leases, similar problems appear as with full property titles. In many cases, the owners of ELCs have more than the allowed maximum of 10,000 hectares [7]. As of 2010, some 1.3 million hectares of land have been given by ELC (officially reported: some 1.0 million hectares), whereas the total arable land is some 3.8 million hectares. Hence ELCs obviously support the trend of rising inequality in land ownership: According to the World Bank, 20-30\% of land owners hold $70 \%$ of the land, while the poorest $40 \%$ occupy only $10 \%$ [8]. Whereas land was distributed almost equally in 1989 (beginning of privatization), the current inequity of land distribution (measured by the Gini coefficient, which is 0.65 ) is the highest among South East-Asian countries [9]. Land concentration and inequity in land distribution was connected with a rising degree of landless and land-poor households. While $91 \%$ of poor people are living in rural areas (2004) [10] and most of them depend on land and agriculture for survival, 20\% of rural families are landless and $25 \%$ are land-poor (that is, they own less than 0.5 hectares) [9,11]. Land concentration and the lack of access to land is a current issue of land disputes. Furthermore, industrial farming is considered unsustainable (e.g., deforestation). ELCs are connected with large monoculture plantations, which may endanger biodiversity and contribute to soil erosion [12,13]. In the long run, the lack of access to land, the export orientation and the soil degradation may impact food security. 
For sure, Germany, China and Cambodia have significant differences in institutions, governance and the manifestations of land use problems. These differences are of great importance for the manner in which land use changes are happening. Nevertheless, the purpose of this article is not to point out these differences [14]. Instead, we want to illustrate the fact that despite all of these differences in governance, the countries have one thing in common: unsustainable land use changes are mostly driven by external effects. These externalities give incentives to violate regulations and cause pressure on land use planning to act in a way that is not optimizing the wellbeing of society.

\section{Spatial Planning, External Effects and Regulations}

\subsection{Spatial Planning: An Answer to External Costs}

What would the world look like if there were no rules for land use or no spatial planning? In Germany, for example, most households could realize their dream of isolated dwelling houses close to nature. However, if everyone did this the spatial patterns would be disastrous, the costs (loss of nature and biodiversity, supply with infrastructure etc.) would be high. Nevertheless, everyone would pursue their individual plan of a remote and isolated house if the costs could be shifted to other people and to society (externalization of costs). Thus, by pursuing the individual actor's interests, an optimum for society cannot be achieved. This leads us into a prisoners' dilemma, we get a Nash equilibrium [15], because nobody can benefit by changing his or her behavior while other people keep their behavior unchanged. This prisoners' dilemma is connected in most cases with external costs. Standards, rules, regulations and also spatial planning are an attempt to deal with such external effects, if the costs (or opportunity costs) appear to be too high for society. However, spatial planning does not only act in economic dimensions; the results cannot be assessed only in monetary terms. In fact, spatial planning has to manage a multidimensional system. It has to balance the competing demands of various stakeholders, and hereby not only consider the willingness to pay or benefits and costs that can be expressed in monetary terms.

\subsection{Spatial Planning and Property Rights: Common Problems though Different Institutional}

\section{Frameworks}

The property rights regime, which determines the degree of freedom to sell the land, has to be considered in connection with the planning and regulation system, which is a restriction of the property rights. Looking at different countries, we find different property rights systems and more or less sophisticated regulations to control land conversion:

In Germany, private property in land is dominant. Land owners basically have a strong position, and most of the farmland and construction land is owned privately. However, the potential and possible use of the plots is planned. The possibilities of owners to use their property are limited (Art. 14 of the German constitution). Germany has tight regulations for farmland conversion (e.g., the Federal Planning Act—Raumordnungsgesetz and Federal Building Code-Baugesetzbuch). Germany is a federal state, and the governmental structure consists of the federal government, state governments, district and municipal governments. The spatial planning process at the federal level is based on the Federal Planning Act (Raumordnungsgesetz), which contains provisions on the conditions, functions 
and guidelines of spatial planning. This law does not specify any details on land use. Spatial planning at the state level is focused on providing a prescriptive outline for land use in each state, or for specific regions covering more than one state, based on the guidelines provided by the federal level. German municipalities have a large degree of independence (Art. 28 of the constitution). Nevertheless, their development and zoning plans should follow the higher-level spatial plans.

The land ownership system in China is quite different to Germany. China has a system of public land ownership. Urban land and natural resources are state-owned, while suburban and rural lands are collectively owned. In regard to state-owned urban land, both public sector and private agents can obtain land use rights through the so-called double-track system [3]. One track is to obtain state-owned land use rights by granting without payment or in consideration of a small land use fee. This method is usually applied in the public interest whenever public entities apply for land use rights. These land use rights cannot be transferred, or may only be transferred after payment of a fee. The other track is to buy state-owned land use rights from the state through auctioning, tendering or a negotiation process, which is usually applied in the case of commercial developments by private developers. This type of land use right may be transferred, rented or mortgaged to any third party in the land market. In contrast, suburban or rural land is under collective ownership. It belongs collectively to the farmers of a village. The collective ownership rights are represented by township and villagers' committees or villagers' groups. Rural land in present-day China is not only a means of production but also a means (in fact, the only means) of social security [16]. Land serves as a substitute for unemployment benefits (particularly for migrant workers) in the event that a villager is dismissed from, or unable to find, off-farm employment. Agricultural land is allocated by the collective to each peasant household on the basis of family size, and peasants have been given the right to use the contracted land for 30 years since the late 1990s. Land conversion is often decided by local authorities in order to change the land for commercial purposes. These land conversions were often connected with expropriations. In the past, there was no proper certification system for the land which could serve as legal proof in case of conflict [17]. Tenure security for the farmers was low. These unclarified aspects and the incompleteness and instability of property rights created rather disorderly conditions for land use management. The Chinese government recognized at an early stage the impacts for farmland conversion as well as for food security, and passed some important legislation in order to preserve China's farmland, including the Basic Farmland Protection Regulation (passed in 1994) or the New Land Administration Law (passed in 1999) [3]. These laws propose a so-called zero net loss farmland policy and seek to protect environmentally sensitive and agricultural lands. Furthermore, the Land Law (1998) and the new Property Rights Law (2007) form a legal basis for necessary land conversion and provide a statutory position on land use planning, which is an important instrument for the government in controlling farmland conversion [14]. Land use planning is the government's responsibility. The structure of the government consists of the central level (state council), and the provincial, municipal, and prefecture and township levels. Higher-level governments have absolute administrative power over the lower levels. The different levels of government are responsible for making Land Use General Plans (LUGP). Within these LUGPs, a quota system is the most important instrument to constrain farmland conversion. Lower-level LUGPs have to seek approval from higher-level LUGPs. Hence, compared with Germany, the planning system is more hierarchic. Nevertheless, enforcement and compliance are not considered to be very strong. 
In Cambodia, land can only be used for private purposes (such as ELCs) if it is converted beforehand from so-called "state public land" into "state private land". Furthermore, there are a number of protection laws (e.g., forestry law). Since 1989, the Royal Government of Cambodia (RGC) has tried to privatize land. The distribution was made according to the size of the families and the availability of land by the communes. In the beginning of the privatization process, almost no proper land titles were given to the people. Meanwhile the allocation of proper land titles has advanced: By July of 2009, approximately 1.5 million parcels had been registered and 1.1 proper land titles had been allotted to the people [18]. All in all, 2.5 million hectares have been given to privates. In Cambodia, a spatial and land use planning system is only in place in some municipalities and districts, but not for the whole country [19]. To date, planning is based on a bottom-up approach. In particular, there is a lack of planning on the regional and the central levels. To date, compliance with the regulations is low. Despite the privatization policy, $80 \%$ of Cambodian territory is still owned by the state [20]. However, this also comprises the abundant ELC holdings. The applications for ELCs have to be approved at the central government level by the Ministry of Agriculture, Forestry and Fisheries (MAFF). From September 2008 onwards, only the MAFF has the authority to grant ELCs. Since September 2008, provincial or local authorities are no longer involved in the application process (Sub-Decree No. 131 on the Modification of the Sub-Decree on Economic Land Concessions, Article 1).

Trying to identify patterns, at first glance it seems that in highly developed countries such as Germany, private property in land is strong, whereas the planning system is also sophisticated. In less-developed countries the property rights seem to be weaker; at the same time the planning system is less developed and governance is poor by comparison. At first glance the German system seems to be superior and a kind of blueprint for less-developed countries. Indeed, this blueprint is also "exported" by development assistance. The Chinese system is certainly working better than the Cambodian system. However, all three countries have severe shortcomings in the effects of regulations on controlling land conversion.

Between 1993 and 2006, the average growth of areas used for settlements and traffic in Germany was between 104 hectares per day (2005-2008) and 129 hectares per day (1997-2000) [21]. The largest portion of converted land was farmland.

In China, the total area of arable land was some 130.1 million hectares in 1996 (1.951 billion mu). By 2007 it had dropped to some 121.7 million hectares (1.826 billion mu). The per capita area of arable land was $1.59 \mathrm{mu}$ in 1996 and $1.39 \mathrm{mu}$ in 2006 [4,22].

As described above, ELCs are the main legal instruments for investments in agro-business. Sub-Decree No. 146 on ELC (Art. 4 and 5) stipulates that environmental and social impact assessments have to be completed in accordance with the land use planning, and that public consultations have to be conducted with local authorities (e.g., Commune Councils) before starting the ELC project. However, ELCs can also be granted through "unsolicited proposals" where the investor itself proposes the demand for the project including planning and construction materials due to a lack of land use planning documents and authorities' capacities to follow the requirements mentioned in Sub-Decree No. 146. The consequence is that many ELCs are affected by encroachment problems, because the required procedure (e.g., Social Impact Assessments and Public Consultations) has often not been complied with [6]. This makes an efficient use of the ELCs difficult, even if the land holder wants to use them. Furthermore, Environmental Impact Assessments are also not carried out as 
required. For instance, illegal deforestation is not only carried out by smallholders, land-poor and landless people, but also by holders of ELCs [9]. The deforestation rate in Cambodia is one of the highest in the world. Despite the introduction of the forestry law (2002), the rate of deforestation is currently increasing [23].

Table 1 provides a short overview of the different institutions and regulatory systems in the countries compared, as well a comparison of how the problems are manifested.

Table 1. Differences in institutions and problem manifestations.

\begin{tabular}{|c|c|c|c|}
\hline & Germany & China & Cambodia \\
\hline Planning type & $\begin{array}{l}\text { Top-down, but with crucial } \\
\text { role of municipalities for } \\
\text { implementation }\end{array}$ & Top-down & Still only bottom-up \\
\hline Planning system & Regulated & Hierarchic & Not effective nationwide \\
\hline Enforcement & Comparatively good & \begin{tabular}{|l} 
Serious \\
shortcomings
\end{tabular} & Poor \\
\hline $\begin{array}{l}\text { Main land } \\
\text { ownership }\end{array}$ & Private & State or collective & $\begin{array}{l}\text { Approx. } 80 \% \\
\text { state-owned (also ELC land), } \\
\text { but privatisation policy }\end{array}$ \\
\hline Issues of concern & $\begin{array}{l}\text { Extension of construction } \\
\text { land, economic, ecological } \\
\text { and social costs of urban } \\
\text { sprawl etc. }\end{array}$ & $\begin{array}{l}\text { Food security, land } \\
\text { degradation, } \\
\text { relocations etc. }\end{array}$ & $\begin{array}{l}\text { Land concentration, } \\
\text { landlessness, equity as well as } \\
\text { efficiency of land use, illegal } \\
\text { land possession, or } \\
\text { underutilization of land, } \\
\text { ecological degradation }\end{array}$ \\
\hline Political target & $\begin{array}{l}\text { 2020: reduction of daily land } \\
\text { conversion to } 30 \text { ha/day }\end{array}$ & $\begin{array}{l}120.0 \text { million ha. } \\
\text { farmland as "red } \\
\text { line" }\end{array}$ & $\begin{array}{l}\text { Facing challenges mentioned } \\
\text { above within the "rectangular } \\
\text { strategy" of the RGC }\end{array}$ \\
\hline
\end{tabular}

Subsequently we wish to demonstrate that externalities are not only a cause for the introduction of land use planning rules, but also for the failure of these regulations.

\section{Externalities, the Bias of Spatial Planning and Pressure on Land Conversion}

\subsection{Land Use Changes and Externalities: The Lack of Neutrality of Spatial Planning}

In most cases, land conversion causes a higher land rent. Any land rent " $\mathrm{R}$ " is much higher for construction land (settlements, industrial areas, etc.) than for agricultural land. At least in developing countries, " $\mathrm{R}$ " is often also higher for agro-industrial production (cash crops, often for exports) than for breeding food crops for subsistence or local markets, which is mostly performed by smallholders. On the basis of Ricardo's "capitalization formula", the value of land "V" can be explained by the discounted land rent: $V=R / i$, where " $R$ " is the annual rent and " $i$ " is the discount rate. In a more complex explanation, we also need to add the value of flexibility of an unimproved site in order to get an "extended present value", as the real option approach does [24]. The land rent can be explained as a "differential rent", which is a function of location [25], the quality of the land [26] and differences in 
the intensity of cultivation or use. Hence, rents on unimproved land are normally not based on labor input. The theories mentioned were originally created for agricultural land, but they can be applied to any kind of land if certain modifications are made. The most important realization for our purpose is that land use changes usually go hand in hand with higher land rents and an incremental value. Subsequently we will illustrate that mostly private sector actors and local governments benefit from these land rents and the incremental value. Very often, land use changes are promoted by a closely connected group of powerful interests.

In Germany, many farmers are also land owners. If the land use plan is changed and land is rededicated from farmland into construction land, the value of the converted land may easily become 20-50 times as high as the value of farmland overnight. Hence the farmers are the main beneficiaries of conversion. If developers are involved in the process, they may also skim off some of the incremental value. All beneficiaries are pushing the conversion process.

In China, a large part of the incremental value of land conversion is taken by the local governments. However, a considerable share is also taken by private actors. Tan et al. mentioned a case in which the compensation of farmland given from the state to the farmers' village committee was $28 \mathrm{Yuan} / \mathrm{sqm}$. Depending on the mechanism used (negotiation, tender or bulletin), the price taken from the state by selling the rights to private land users was between 237 (negotiation) and 577 Yuan/sqm (bulletin, which is a kind of flexible auction). In the secondary market the land could be sold for 635 Yuan/sqm. In the past, the farmers received low compensation and did not participate in the higher rent of the developed land [14]. New regulations approved by the CPC Central Committee in October 2008 may hopefully contribute to better participation for the farmers. In the past, illegal land conversion was also pushed by farmers in order to obtain a larger piece of the cake. Ding [3] reports on farmers selling their land use rights to developers in the early 1990s generating revenue that was 200-300 times higher than their annual yields from farm production. Legalizing land transfers by introducing tradable user rights may give the government more control over the conversion process. On the other hand, the farmers, too, will push the conversion of farmland into construction land in order to realize its incremental value. Thus, Thiel [27] concludes that the strengthening of property rights of the farmers and the integration of tradable land use rights into the spatial planning system will be a challenge. Also, new kinds of social problems may emerge. Thiel warns against property accumulation, landless migrant workers and landless farmers.

In Cambodia, due to extremely low leasehold fees (0 US \$ to 10 US \$ per year and hectare [28] and tax holidays, most of the incremental value is reaped by the holders of the ELCs. Other beneficiaries are also corrupt politicians and administration officers, which are paid for tolerating the violation of laws.

We have to stress the fact that not only private actors are participating in the higher rents and the incremental value resulting from land conversion.

In Germany and China, the communes also hope to receive more revenues from land conversion by fees, taxation or the financial equalization scheme. In Germany, municipalities try to increase revenues by attracting inhabitants and firms; hence they are zoning new development areas (in competition with each other). In China, local governments need the revenues of land conversion due to a weak and decentralized tax system [29]. Hence, developers appear as particularly distinguished guests for local government officials. Often the local cadres' demand for land development is far beyond the supply of 
projects proposed by developers. Regarding ELCs in Cambodia, the RGC (Royal Government of Cambodia) hopes that the firms will develop remote areas by supplying infrastructure and create tax revenues in the future [30].

Furthermore, local politicians may be promoted in case of successful attraction of new industries: In Germany, the creation of new development areas is often considered a performance indicator for mayors. The chances of being re-elected increase. Also in China local officials are easily tempted to sacrifice farmland or rural development to achieve a higher rate of economic growth [3], because urbanization and industrialization are regarded as indications of a strong performance of local leaders.

In contrast to Germany and China, but similar to many other developing countries, a lack of capacities and formal power means that Cambodian municipalities cannot yet be considered the driving forces of land conversion. The central government and the provincial authorities play a larger role instead.

According to the findings of the New Political Econom and Public Choice Theory, the leaders of the (local) governments are also utility-maximizing agents, which do not primarily pursue an optimizing of the common good but of the individual benefits (see Section 2.3.) [31]. In order to achieve the individual targets of the governmental decision-makers, land is given to firms often at very favorable terms, which may be considered as subsidies.

These subsidies may be justified with external benefits of land use changes, which also have to be taken into account. For example, private investments may create jobs and increase the income of the people and the state. However, an assessment of such external effects is difficult. Furthermore, there is a regulation problem, which shall be described by focusing on infrastructure. Basically, infrastructure is considered a public good and the provision of infrastructure is a task for the public sector.

However, due to a lack of financial capacity of the state, development in Western countries is based more and more on Public Private Partnerships (PPP). In many cases, the plans (that should consider the common good) are adapted to the wishes of the developers, with consequences such as a lack of public space or too much density [32]. There is nothing to argue against privates acting as agents of the state. It is not the task of authorities to drive trucks. Private agents should also receive fair compensation for their development efforts according to clear rules (cost covering), and not speculating on the incremental value (value capture is not the economic task of developers). Hence, developers should be paid by tax revenues instead out of the incremental value. If the incremental value goes to the public and the development is paid out of taxes, there is also more transparency in the development process. The flip side of taking away speculative chances from developers is more security for them. Furthermore, they have fewer incentives to lobby the planners. Hence, the current method of financing development out of the incremental value (as is often done in Germany for example, connected with PPP) cannot be considered good governance.

In China, some land services are carried out by the government (roads, electricity, piped water, levelling). After that, land use rights are conveyed or allocated to land developers (including the private and public sector). The developers provide drainage systems, gas for cooking, communication infrastructure and heating systems [14]. Hence, the incremental value is shared among the government and the developers in order to cover development costs and to obtain profit. However, there is a lack of transparency about how the benefits are distributed among the actors.

In Cambodia, the private provision of infrastructure as a precondition for economic development is of great importance. For instance, the economic success of Thailand was also based to a large degree 
on the governmental emphasis on the supply of infrastructure [33]. Hence, because the RGC lacks financial power and is apparently also unwilling to do the same, agro-industrial investors are encouraged to engage in Private Participation in Infrastructure ("PPI"), connected with the use of ELCs [30]. Basically, there is nothing to say against PPI. However, often there is a lack of transparency in the ELC contracts, particularly if they are connected with PPI. Also, compliance with the contracts has to be monitored, but there is a lack of capacity. Naturally, the engagement of private and profit-orientated companies in PPI may produce external benefits. However, getting fair compensation for investors and developers (cost covering) is not the same as a license for rent seeking and value capture. Low ELC fees that are paid according to production [6] are blanket subsidies (value capture). Such blanket subsidies are not a good way to compensate external benefits. This statement basically holds for any subsidies of investments in the agriculture sector. Such subsidies might be necessary, because the profitability of investments in agriculture is often low, particularly in developing countries, and a developed agricultural sector causes manifold positive external effects. However, due to the antagonism of interests of developers or other investors and the public, transparent and clear rules of cost covering should be put in place in order to contribute to good governance.

Whereas the winners of land use changes (higher land rent, incremental value) are mostly small and well-organized groups that work in close collusion with the (local) government in order to participate in the land rent and the incremental value, the costs are pushed onto weakly organized groups or onto society as a whole. The larger a group, the more difficult it is to organize and protect its interests [34].

One might argue that many countries have regulations to shift at least part of the direct costs of land use changes to private beneficiaries. In China, the up-front payment for leasing land also contains an urban infrastructure fee and a community infrastructure fee [29]. In Germany, there are similar land improvement contributions that have to be paid. In Cambodia, comparable regulations are not yet in place. Nevertheless there is evidence that such contributions only cover a fraction of the costs of the technical and social infrastructure [35]. If, for example, a new settlement means that a new school or a new hospital has to be set up in Germany, in most cases the commune or the county is in charge and not the developer. Hence, a lot of costs are externalized. Though, to my knowledge, such financial assessments are not made for China or Cambodia, there is no evidence that the situation is any different there.

However, even more attention should be given to the opportunity costs of planning. Private investment decisions are considered efficient because private investors normally take opportunity costs into account. For example, in a net present value calculation the discount rate serves as such an opportunity cost rate. Hence, the investor always compares the performance of the intended investment with the performance of the next best investment alternative. However, not only private investments but also planning decisions cause opportunity costs. If the land use plan favors a certain use (e.g., settlement), other uses cannot be realized (e.g., commerce or agriculture). Various stakeholders compete with each other; hence, land use planning always causes opportunity costs. Whereas private investors reap a great deal of the benefits of land use changes (incremental value, higher land rent), they do not have to take any opportunity costs into account. Instead, the opportunity costs are externalized. The external costs due to degradation of environment, the loss of biodiversity, etc. can also be interpreted as opportunity costs (lost benefits from environment). The same holds true for 
destruction of livelihoods (lost income chances), which are often caused by resettlements and evictions (e.g., China and Cambodia).

The examples of externalization of costs are manifold:

In Germany, open land conflicts as such appear seldom. However, there is no win-win situation. The costs of land conversion (such as loss of biodiversity, higher costs of infrastructure etc., see above) are shifted to society as a whole. Society as a whole is the most poorly organized group and the most difficult to organize. Hence, external costs are often shifted onto society (although there is some resistance from "NIMBY" groups - "not in my back yard").

In rural China, peasants are organized in cooperatives. Such a cooperative is a loose organization without strong common interests [17]. Peasants have hardly any political bargaining power when land expropriation is underway. Laws to protect the farmers' interests are unable to stop this development because the economic incentives are stronger. Chinese society is also affected, e.g., by the loss of food security.

In Cambodia, the social costs of ELCs are often shifted to vulnerable groups: Almost half of the ELCs are linked to problems with land disputes, caused by resettlements and evictions [6]. Mainly human rights organizations or NGOs (such as LICADHO or Star Campuchea, etc.) care for the rights of the victims of land conflicts. Courts are not considered to be independent.

Generally, we may consider a decoupling of marginal benefits and marginal costs of land use changes. This decoupling has consequences for the way in which land use planning is carried out. The authorities in charge are not neutral, and the decoupling of benefits and costs is like an invitation to the beneficiaries for a free lunch. In almost every country, powerful interests are trying to lobby and to manipulate the authorities in charge by legal (participation process!) and sometimes also by illegal means. However, a "captured" (local) government is no longer a neutral trustee of the common good. In an overview of the Global Corruption Barometer, land services are ranked No. 3 in the corruption scale in a general overview [36], and not only in developing countries.

\subsection{Inefficient Land Use and Externalities: The Lack of Compliance with Land Use Planning}

Another big issue related to external effects, is the lack of compliance with the land use plans of private sector actors. One manifestation of the problem relates to unused sites. This problem emerges to a larger degree due to the real option character of land [24]: The owner of land has the right but not the obligation to exercise the option. For example, many firms hold land as reserve plots. The plot is only used according to the plans if the individual situation is appropriate (e.g., if a new storehouse is needed). If plots are bought in good locations, the owners do not lose money by leaving them unused, because the value of the plot will rise over time. Furthermore, unimproved plots have a higher value than a developed plot because all improvement options are still open (many assessors give a discount on the value of improved land of 10 to 20\%). The consequence is that leaving sites unused may be rational economic behavior and cause a shortage of supply of land. For example, the share of unused area for settlement and traffic in Germany is around 4\% of the total area [37].

Another variation of this problem is the underuse of sites:

For example, in Germany many elderly people are living in houses that are too big for them (e.g., because their partner has died, the children have moved to other places). Although they do not 
have enough money to maintain their houses, they do not rent out parts of the property. The result is that many houses in the center of villages are badly maintained and underused, many village centers are "decaying" like an old apple. Instead, new development areas are made available at the edge of the villages. This development is connected with a loss of infrastructure, less quality of life and a decline in the attractiveness of the villages. The list of examples could be extended arbitrarily. Also the intensity of use is sinking. Whereas the density of settlement in 1992 was still 2,000 habitants $/ \mathrm{km}^{2}$ of the settlement and traffic area, by 2008 it had fallen to 1,742 habitants $/ \mathrm{km}^{2}$, a decline of $12.8 \%$ [38].

For China as an emerging economy, the situation is quite different from that of Germany. Scarcely any current data are available. The first land survey was from 1996, the data from the second land survey were not yet available when this article was finished. The data from the Communiqué on Land and Resources of China, published on the homepage of the Ministry of Land and Resources P.R.C. [39], are in some aspects not compatible with the data from the first land survey. Nonetheless, we can derive a general trend from the data of the first land survey: The population density in China was increasing if the population is related to the whole area (1949: 57 people $/ \mathrm{km}^{2}-1995: 127$ people/ $\mathrm{km}^{2}$ ). Nevertheless, if the population is only related to the area that is used for settlement, mining and transport (roughly comparable with the area for settlement and traffic purposes mentioned above), the density of settlement was decreasing from 80 people/ha (1949) to 41 people/ha (1995) [40]. However, this development cannot be interpreted as low efficiency considering the fact that the starting conditions in China are also very low. Due to the economic upswing, in the last years it was mainly the area for transport that was growing rapidly.

In rural Cambodia, the problem of underused sites exists. Only some $10 \%$ of the ELCs granted are in use [7,9]. Many ELCs are held only as a kind of option or for speculative reasons [41]. The royalties for ELCs are calculated on the bases of production and do not create pressure to put the land to use [28]. Leaving ELCs unused is a failure to fulfil the conditions of granting ELCs; recently the RGC cancelled the first ELCs due to the violations of the contracts [7].

In Germany as well as in rural Cambodia, people and firms claim for land that they do not really need — on the other hand, people and firms that need the land do not have access. In both countries, the inefficient use of the plots creates in most cases individual monetary or non-monetary benefits for the holders of the plots. However, in most cases the costs are shifted again to society: An inefficient use of land works like a shortage of supply. Due to this shortage of supply, German planners are often pushed to make more land available by changing the land use plans. Urban sprawl and land consumption is rising, with consequences for biodiversity, costs of infrastructure, social costs and opportunity costs. In rural Cambodia, land concentration, inequality and land disputes are increasing; The Social Land Concession program (land shall be allotted to landless or land-poor people) is making slow progress because not enough land can be made available.

\section{Coupling of Benefits and Costs of Land Use by Means of a Site Value Tax}

In Section 3.1., we showed how land rent seeking causes direct pressure on authorities to support land conversion. In Section 3.2., we described how inefficient land use itself may put indirect pressure on land conversion. Both problems have been connected with external costs, and both problems could be eased by means of an intelligent property taxation regime (or a sensible leasehold system): 
Firstly, let us discuss the first problem (lack of neutrality of planning), mentioned in Section 3.1.: Economists mostly discuss how to assess the externalized costs and how to internalize them, e.g., by taxation. However, the assessment of externalities is difficult, expensive and always the issue of debate. However, the target of the site value tax would be the transfer of a great deal of the land rent from the private sector actors to the public/state and not the internalization of external costs. Hence, the design of such a tax would not be the same as in an internalization approach. The idea of a tax is therefore basically to skim off huge parts of the land rent. This idea was heavily promoted by Henry George [42]; before him, David Ricardo [26] also thought about skimming off the land rent with a tax. In order to avoid a misunderstanding, it should be noted that although such a tax should skim off part of the land rent, the land rent itself cannot and should not be abolished. The land rent is an important allocation force that regulates the use of the land [43]. High land rents cause (opportunity) costs that normally only valuable investments may cover. Although no tax is capable of abolishing the land rent, it may allocate it to the public. Land rents emerge mainly due to activities of the state (planning, infrastructure supply etc.), whereas the public bears a huge part of the costs of land use changes. Thus, private reaping of land rents can hardly be justified. If the benefits of an increased land rent can be reaped privately and the costs can be externalized, this arrangement supports land rent seeking and causes bad governance. An intelligent tax system should try to achieve a better coupling of benefits and costs of land use (changes) by changing the allocation of the land rent. The more consistent the reallocation of the land rent to the public, the better the conditions for good land use policy. If the land rent were skimmed off completely (as Henry George wanted), land use could be implemented efficiently. Nowadays, the land rent is also skimmed off almost completely in Western private property systems by private landlords in leasehold or with rent contracts. For example, in Germany in 2007 around $62 \%$ of all agriculture was carried out on leased land [44]. Around 58\% of the population lived in rented flats. However, in contrast to Henry George's tax, our proposal intends to skim off only a fraction of the land rent (see below); otherwise the acceptance of the tax would suffer.

The second problem (lack of compliance and efficiency, Section 3.2.) could be solved by putting economic pressure on the owners to use the site efficiently. If they do not want to or cannot use the site efficiently, they should have an incentive to sell the site to other actors who can make better use of it. If someone is damaging society with an inefficient use of plots, he should pay for that damage (costs-by-cause principle). The owners of property should also get incentives to maintain their buildings in order to obtain high rents from them - in order to be able to earn the rents to pay the tax.

Both requirements could be achieved with a fixed tax on the value of unimproved land (site value tax):

First of all, the tax base should not be compound (i.e., should not include the value of the building and fixtures), because a compound tax base discourages efficient land use: The better the use of a site (by building and other fixtures) and the higher the resource efficiency, the higher the tax. Furthermore, a compound tax base always has to be changed if the improvements are modified. Hence, the improvements should have to be monitored and registered on an ongoing basis, which causes high costs. In principle, what makes assessment of property difficult is not so much the assessment of unimproved plots, but the assessment of the buildings (and fixtures, if included). The taxation of buildings and fixtures may also cause distortions [45]. Moreover, a compound tax base is difficult to justify: By taxing buildings and fixtures, a compound tax base charges the efforts of the owners of improving the land. Instead, a tax on unimproved land only takes away parts of the land rent, which is 
not determined by efforts of the owners, but by actions of the public or by coincidence. The assessment of the base of a site value tax could be carried out by committees based on the blueprint of the German land assessment boards ("Gutachterausschüsse", § 192 BauGB), which are public land assessment service agencies. These boards collect data of all land transactions and set out annual guiding values for unimproved land ("Bodenrichtwerte") for zones of plots with similar characteristics. These guiding values are also used for taxation. Without a doubt, a great deal of time and effort is required to build the capacity for doing this. Development assistance for threshold and developing countries should emphasize this point and suggest a clear blueprint for the function of the boards.

The tax rate on unimproved land should be fixed, thus the tax should be charged without regarding the actual land use. The supply function of land is probably not completely steep; otherwise hoarding and underuse of sites could not be explained [46]. However, due to the fixed-cost character of the tax, the land owner cannot avoid the tax or shift it to the tenant. The only way to lower the effective tax burden is to use the site efficiently, according to the plan. Because this tax does not cause any tax wedge, not only land reformers but even liberal economists such as Milton Friedman supported such a tax [47]. Hence, the tax proposed below is anything but a straight road to socialism.

A comparable approach was already used in Qingdao (China) in 1898 [48]. The system was set up during the colonial era by a German administration officer named Schrameier, who between 1924 and 1925 was also an advisor to Sun Yatsen. If such a system could be introduced before 1900, developing and threshold countries such as China and Cambodia should also be able to do the same today. However, in many threshold and developing countries (such as China and Cambodia) there is no operational legal cadastre and assessment regime yet. It is necessary to build the capacities and institutions as well as to achieve proper land assessment. Such a tax cannot be introduced from one day to the next. Nevertheless, even in the absence of a legal cadastre, local authorities could install a fiscal cadastre in order to identify and value a plot of land and post a public notice that this particular piece of land owed a given amount of tax. If no-one steps forward to pay the tax, the government could seize it [49].

\section{5. (Local) Governments and Good Governance}

Above (Section 3.1.), we demonstrated that local authorities also have financial and political incentives to promote land conversion. On the other hand, the costs of land conversion are shifted to higher administrative levels (more need for infrastructure, of which the county, the state or the federation is in charge), neighboring communes (sometimes we have destructive competition among communes for inhabitants and investors) or society as a whole (loss of biodiversity, etc.). Hence, the actions of governments are also connected with external costs. Particularly the local governments cannot be regarded neutral actors and trustees of the common good. In consequence, there is a lack of compliance with the higher-level plans (e.g., regional planning, if existing). However, the central role of municipalities in land use planning should not be put into question. Central governments do not have enough information and capacity to make comprehensive plans for the lower administrative levels. Besides, only the involvement of the communes guarantees "ownership" for the plans. Nonetheless it is not an intelligent arrangement to give the municipalities such an important role in 
land use planning and to make them at the same time depend on the financial sources of land use changes.

Germany is an extreme case of poor institutional design: On one hand, German municipalities are crucial in implementing the higher-level plans; at the same time they enjoy a large degree of political autonomy (Art. 28 of the constitution). On the other hand, the municipality's right to collect the property tax (created by new settlements, attracted industries, etc.) on land is even fixed in the constitution (Art. 106). In such an arrangement, there is a temptation for authorities to increase the revenues by promoting land development and land conversion. Due to a weak and decentralized tax system, Chinese municipalities also depend on the revenues of land conversion.

However, the solution for the regulation problem is basically simple: Local governments should not be direct beneficiaries of land use changes. The widespread opinion, claiming that property tax on land is a "born" communal tax, is misleading. In order to make local governments more neutral, the money raised by land use changes should better be integrated into a financial equalization scheme. The funds should be transferred to a higher administrative level and be pooled there. Finally, the money could be redistributed to the local governments according to the size of the local population if possible ( $c f$., the idea of the "Baulandausweisungsumlage", as it was discussed in Germany [50]). Unproductive competition between the municipalities, as is currently happening in Germany, would be lowered. Land conversion would no longer provide any direct financial benefits to the local governments. On the other hand, local governments would still have incentives to care for the attractiveness of their townships in order to attract more people (and so get a higher share of revenues) and to achieve political promotion. Nevertheless, the local governments as a whole would have as much revenues as before; they would neither win nor lose anything. Local governments would also participate in the land rent, but in an indirect way.

\section{Conclusions}

Politicians and scientists have realized that land use is happening in an unsustainable way and that changes are necessary. Externalities can only be managed by regulations if private negotiations do not work, e.g., due to high transaction costs [51]. Regulations always cause a dilution of property rights, thus the basic idea of achieving good governance by strengthening the whole bundle of property rights (Table 2 below) is misleading. A complete ownership title may be interpreted from an economic viewpoint as holding all four sets of the rights mentioned below (the following classification is abstract, but derived from Roman law [52].

The question is: What kind of dilution is compatible with good governance in a market economy? The "traditional" answer is the introduction of a set of new regulations and efforts to enforce them. Although Germany serves as a blueprint for many developing and threshold countries, the property rights of private land owners are diluted by a huge number of public laws [53], particularly the rights to control and to use the land. In contrast, the rights due to value and rent are scarcely negatively affected. Many regulations and public bureaucracy impact on "usus" and "abusus". Building orders ( $\$ 176$ Federal Building Code—Baugesetzbuch, BauGB), modernization orders ( $\$ 177$ BauGB), development reduction orders ( $\S 179$ BauGB) and compulsory purchase in relation to urban development plans are just some examples of regulations put in place to bring the behavior of the 
owners in line with the land use plans. Although this is the usual way of thinking of administration officers, it is neither effective nor efficient. Such a policy of "command and control" by introducing a great deal of red tape is anything but good governance. It cannot achieve its goals as long as there is a strong counteracting force based on the decoupling of benefits and costs of land use change.

Table 2. Dilution of property rights (from an economic point of view).

\begin{tabular}{|c|c||c||}
\hline Exclusive rights, based on & Value and rent & Control and use \\
\hline Asset (stock) & $\begin{array}{c}\text { Right to sell the asset and to participate } \\
\text { in its value } \\
\text { (disposal, Latin: "ius abutendi") }\end{array}$ & $\begin{array}{c}\text { Right to control and to change } \\
\text { the asset according to one's } \\
\text { needs (Latin: "abusus") }\end{array}$ \\
\hline $\begin{array}{c}\text { Utility (flow) } \\
\text { Controlling the behavior of } \\
\text { the private investors }\end{array}$ & $\begin{array}{c}\text { Right to appropriate any returns on the asset } \\
\text { (Latin: "usus fructus") }\end{array}$ & $\begin{array}{c}\text { Right to use the asset } \\
\text { (Latin: "usus") }\end{array}$ \\
\hline $\begin{array}{c}\text { Traditional way: } \\
\text { e.g., purchasing consents, subsidies } \\
\text { Alternative way (cost-by-cause principle): } \\
\text { Negative economic incentives, such as } \\
\text { taxation or leasehold }\end{array}$ & Traditional way: Regulations \\
\hline Consequence & $\begin{array}{c}\text { Dilution of the rights due to value and rent } \\
\text { (cost-by-cause principle) }\end{array}$ & $\begin{array}{c}\text { Dilution of the rights due to } \\
\text { control and use }\end{array}$ \\
\hline
\end{tabular}

It is an issue of concern that such bad practice is also exported to threshold and development countries by development assistance and western advisers (e.g., in Cambodia). China has a weak tax system, which has to be developed. Cambodia is a "white sheet of paper"-a comprehensive property tax has yet to be introduced. However, China and Cambodia have the chance of not repeating mistakes other countries have made, if the proposals discussed here were to find their way into political discussion.

Instead of always reacting with new regulations, it would be more intelligent to support the planning system with a suitable economic framework. From a regulatory policy viewpoint, these economic incentives should indeed be negative: It is not a healthy approach to reward those who do not cause damage to society. Otherwise, the price for good land use policy is unaffordable and the elemental problem of the decoupling of benefits and costs of land use changes cannot be solved. Instead, those who cause damage to society should pay (costs-by-cause principle). The proposed tax system also dilutes the property rights of private actors, but only the rights due to value and rent. Yet this is precisely the reason why the restriction of user rights (and tenure security) can be minimized. Meanwhile, some rethinking is taking place. Less regulations and more financial incentives are required e.g., in the Asia Regional Assessment for the FAO Voluntary Guidelines on Responsible Governance of Land and Other Natural Resources [54].

However, the capacity of the tax to contribute to good governance in land use is limited. By analyzing the formula for land value after taxation, $V=\frac{R}{i+t}$ (where " $R$ " is the land rent (before taxation), " $i$ " is the real interest rate (deflated) and " $t$ " is the tax rate), we can easily see that even with a very high tax rate the land rent cannot be skimmed off completely (as Henry George suggested). Therefore, the capability to couple benefits and costs of land use and land conversion is restricted. On 
the other hand the dilution of property rights due to rents and value is also limited. Hence, there should be a certain acceptance if such a tax is introduced.

\section{Central conclusions:}

- Despite huge differences in institutions and governance, unsustainable land use changes in Germany (as an industrialized country), China (as a threshold country) and Cambodia (as a developing country) have some patterns in common: The beneficiaries of land conversion are often well-organized actors (land owners, developers and municipalities), whereas the costs of land conversion are often shifted to poorly organized groups and to society as a whole (externalization).

- Developing the planning system and planning law by itself cannot guarantee a sustainable land use policy. Instead, a better coupling of benefits and costs of land use changes has to be put in place by introducing a sensible financial framework.

- Regarding the actions of private land owners, it is difficult to internalize the externalized costs of land conversion. A more promising approach is to skim off parts of the land rent by means of a site value tax. Such a tax would also result in better compliance with the land use plans.

- Infrastructure is basically a public good, which should be financed out of taxes. If developers act as an agent of the state, they should get fair compensation. However, they should be paid by tax revenues and not participate in the incremental value caused by land conversion (cost covering instead of value capture).

- Land use planning should balance the competing claims of the various stakeholders in order to optimize the common good. However, municipalities become involved in a conflict of interests if they are in charge of planning and at the same time beneficiaries of land conversion. Hence, the revenues of property taxes should be pooled and redistributed among the municipalities, if possible according to the number of habitants (financial equalization scheme).

\section{References and Notes}

1. German Federal Parliament (Deutscher Bundestag). Große Anfrage-Instrumente zur Reduzierung des Flächenverbrauchs; Printed matter Inc.: Berlin, Germany, 2007; Available online: http://dipbt.bundestag.de/dip21/btd/16/073/1607360.pdf (accessed on 6 April 2010).

2. Federal Environment Agency Germany (Umweltbundesamt). Towards More Effective and Sustainable Brownfield Revitalization Policies. In Proceedings of the 2nd International Conference on Managing Urban Land, Stuttgart, Germany, 25-27 April 2007.

3. Ding, C. Farmland Preservation in China. Land Lines 2004, 16, No. 3; Available online: www.lincolninst.edu/pubs/913_Farmland-Preservation-in-China (accessed on 6 April 2010).

4. Jiang, X.; Zhao, W.; Ma, S. Don't move my food-Chinese netizens rebuke economist's attack on farm land bottom line. China View, 26 December 2008; Available online: http://news.xinhuanet.com/english/2008-12/26/content_10563842.htm (accessed on 6 April 2010).

5. Interview with Ralf Symann. DED Cambodia, 9 March 2010. 
6. Economic Land Concessions in Cambodia-A Human Rights Perspective; United Nations Cambodia Office of the High Commissioner for Human Rights: Phnom Penh, Cambodia, 2007; Available online: http://cambodia.ohchr.org/webdocuments/reports/Thematic_rpt/Thematic\%20 Report\%20on\%20ELC_12-Jun-07_eng.pdf (accessed on 2 January 2010).

7. Economic Land Concession, Information Center; Ministry of Agriculture, Forestry and Fisheries (MAFF): Phnom Penh, Cambodia, 2009; Available online: http://www.elc.maff.gov.kh/ index.html (accessed on 14 December 2009).

8. A Fair Share for Women: Cambodia. Gender Assessment; The World Bank: Phnom Penh, Cambodia, 2004.

9. Sharing Growth: Equity and Development in Cambodia-Equity Report 2007; The World Bank: Phnom Penh, Cambodia, 2007; Available online: http://web.worldbank.org/WBSITE/ EXTERNAL/COUNTRIES/EASTASIAPACIFICEXT/CAMBODIAEXTN/0,,contentMDK:2136 8241 pagePK:141137 piPK:141127 theSitePK:293856,00.html (accessed on 8 November 2009).

10. Cambodia: Halving Poverty by 2015?: Poverty Assessment; The World Bank: Phnom Penh, Cambodia, 2006.

11. A Fair Share for Women: Cambodia Gender Assessment; The World Bank, Phnom Penh, Cambodia, 2004; p. 60.

12. Hansen, K.; Top, N. Natural Forest Benefits and Economic Analysis of Natural Forest Conversion in Cambodia; Cambodia Development Research Institute (CDRI): Phnom Penh, Cambodia, 2006.

13. Eswaran, H.; Lal, R.; Reich, P.F. Land degradation: An overview. In Responses to Land Degradation, Proceedings of 2nd International Conference on Land Degradation and Desertification, Khon Kaen, Thailand, 25-29 January, 1999; Bridges, E.M., Hannam, I.D., Oldeman, L.R., Pening de Vries, F.W.T., Scherr, S.J., Sompatpanit, S., Eds.; Oxford Press: New Delhi, India, 2001; Available online: http://soils.usda.gov/use/worldsoils/papers/land-degradationoverview.html (accessed on 14 December 2009).

14. Tan, R.; Beckmann, V.; van den Berg, L.; Qu, F. Governing farmland conversion: Comparing China with The Netherlands and Germany. Land Use Policy 2009, 26, 961-974.

15. Nash, J.F. Non-cooperative Games; Princeton University: Princeton, NJ, USA, 1950; Available online: http://www.princeton.edu/mudd/news/faq/topics/Non-Cooperative_Games_Nash.pdf (accessed on 17 December 2009).

16. Kung, J. Choice of land tenure in China: The case of country with quasi-private property rights. Econ. Dev. Cult. Change 2002, 50, 793-817.

17. Cui, T. Research on the system of field property rights in the Chinese countryside. In Proceedings of ERSEC International Conference on Sustainable Land Use and Water Management, Beijing, China, 8-10 October 2009; UNESCO Office Beijing: Beijing, China, 2009; pp. 75-80.

18. Cambodia Economic Watch; Economic Institute of Cambodia: Phnom Penh, Cambodia, 2008; Available online: http://siteresources.worldbank.org/INTCAMBODIA/Resources/EconomicWatch-October-2008.pdf (accessed on 14 December 2009). 
19. Sub-Decree No. 72 ANK, BK on Commune/Sangkat Land Use Planning Procedure. In Implementation Manual on Commune Land Use Planning-To Support Commune Development Plan and Commune Investment Program; Ministry of Land Management, Urban Planning and Construction, Cambodia (MLMUPC): Phnom Penh, Cambodia, 2009.

20. Project Appraisal Document-Land Allocation for Social and Economic Development Project; The World Bank: London, UK, 23 April 2008; Available online: http://web.worldbank.org/ external/projects/main?menuPK=51447259\&pagePK=51351007\&piPK=64675967\&theSitePK=4 $0941 \&$ menuPK=64187510\&searchMenuPK=51351213\&theSitePK=40941\&entityID=000333037 _20080506000231\&searchMenuPK=51351213\&theSitePK=40941 (accessed on 14 December 2009).

21. German Federal Parliament (Deutscher Bundestag). Antwort der Bundesregierung auf die Große Anfrage (Bundesdrucksache 16/7360)_Instrumente zur Reduzierung des Flächenverbrauchs; Printed Matter Inc.: Berlin, Germany, 2008; pp. 1-28; Available online: http://dipbt.bundestag.de/dip21/btd/16/097/1609720.pdf (accessed on 6 April 2010).

22. Zou, X.; Oskam, A.J. New Compensation Standard for Land Expropriation in China. China World Econ. 2007, 15, 107-120.

23. Mongabey.com Homepage. http://rainforests.mongabay.com/deforestation/2000/Cambodia.htm (accessed on 9 January 2010).

24. Holland, A.S.; Ott, S.H.; Riddiough, T.J. The role of uncertainty in investment: An examination of competing investment models using commercial real estate data. Real Estate Econ. 2000, 28, 33-64.

25. von Thünen, J.H. Der isolierte Staat in Beziehung auf Landwirtschaft und Nationalökonomie, oder Untersuchungen über den Einfluß, den die Getreidepreise, der Reichtum des Bodens und die Abgaben auf den Ackerbau ausüben; Perthes: Hamburg, Germany, 1826.

26. Ricardo, D. On the Principles of Political Economy and Taxation; Liberty Fund: Allison Pointe Trail, IN, USA, 1817; reprint 2004.

27. Thiel, F. Public Land Leasing International-Intelligente Bodenpolitik oder Instrument zum "Land Grabbing"? In Jahrbuch für Bodenpolitik 2008/2009; Dieterich, H., Löhr, D., Thiel, F., Tomerius, S., Eds.; vwf-Verlag: Berlin, Germany, 2010, (in print).

28. Royal Government of Cambodia (RGC). The Fixation of Concession Land Rental Fee; Ministry of Agriculture, Forestry and Fisheries (MAFF): Phnom Penh, Cambodia, 31 May 2000; Available online: http://www.elc.maff.gov.kh/index.html (accessed on 5 March 2010).

29. Deng, F.F. Political Economy of Public Land Leasing in Beijing. In Leasing Public Land_Policy Debates and International Experiences, China; Bourassa, S.C., Hong, Y.H., Eds.; Lincoln Institute of Land Policy: Cambridge, MA, USA, 2003; pp. 229-250.

30. Rectangular Strategy, Phase II; Royal Government of Cambodia (RGC): Phnom Penh, Cambodia, 2008.

31. Cullis, J.; Jones, P. Public Finance and Public Choice, 2nd ed.; Oxford University Press: Oxford, UK, 1998.

32. Bretschneider, B. Hoheitsrechtlich geplant? Architektur Bauforum 2008, 20, 1-2. 
33. Beisinger, C.; Diao, X. Economic Transformation in Theory and Practise: What Are the Messages for Africa? Discussion Paper 00797; International Food Policy Research Institute (IFPRI): Washington, DC, September 2008; Available online: www.ifpri.org/publication/economictransformation-theory-and-practice (accessed on 16 April 2010).

34. Olson, M. The Logic of Collective Action: Public Goods and the Theory of Groups, 2nd ed.; Harvard University Press: Harvard, CA, USA, 1971.

35. Siedlungsentwicklung und Infrastrukturfolgekosten-Bilanzierung und Strategieentwicklung; Final Report; Federal Office for Building and Regional Planning Germany (Bundesamt für Bauwesen und Raumordnung, BBR): Bonn,Germany, 2006.

36. Global Corruption Barometer; Transparency International: Berlin, Germany, 2009; Available online: http://www.transparency.org/policy_research/surveys_indices/gcb/2009. (accessed on 8 November 2009).

37. Schutz der biologischen Vielfalt und Schonung von Ressourcen-Warum wir mit Flächen sorgsam und intelligent umgehen müssen; Federal Environment Agency (Umweltbundesamt, UBA): Dessau, Germany, 2008.

38. Sources: Statistisches Jahrbuch 2008; Statistisches Bundesamt: Wiesbaden, Germany, 2009; Zunahme der Siedlungs- und Verkehrsfläche: 104 Hektar pro Tag, 11 November 2009; Available online: http://www.destatis.de/jetspeed/portal/cms/Sites/destatis/Internet/DE/Presse/pm/2009/11/ PD09_426_331,templateId=renderPrint.psml (accessed on 6 April 2010). Data processed by own calculations.

39. Communiqué on Land and Resources of China 2004 and 2006; Ministry of Land and Resources P.R.C. (MoLR): Beijing, China, 2006; Available online: http://www.mlr.gov.cn/mlrenglish/ magazine/2006/200711/t20071108_90721.html and http://www.mlr.gov.cn/mlrenglish/magazine/ 2004/200710/t20071011_86304.html (accessed on 10 January 2010).

40. Lin, G.C.S.; Ho, S.P.S. China's land resources and land-use change: insights from the 1996 land survey. Land Use Policy 2003, 20, 87-107; Data referring to the population development are available online: http://www.chinability.com/Population.htm (accessed on 16 April 2010). Data processed by own calculations

41. The Report of Land and Human Development in Cambodia; Supreme National Economic Council: Phnom Penh, Cambodia, 2007; Available online: http://www.un.org/esa/agenda21/natlinfo/ countr/cambodia/land.pdf (accessed on 8 December 2009).

42. George, H. Progress and Poverty; William Hinton: San Francisco, CA, USA, 1879; Available online: http://www.progressandpoverty.org (accessed on 12 October 2009).

43. Pfannschmidt, M. Vergessener Faktor Boden-Marktgerechte Bodenbewertung und Raumordnung; Gauke-Verlag: Lütjenburg, Germany, 1990.

44. Situationsbericht 2010-Trends und Fakten zur Landwirtschaft; German Farmers' Association (Deutscher Bauernverband, DBV): Berlin, Germany, 2009.

45. Evans, A.W. Economics, Real Estate and the Supply of Land; Blackwell Publishing: Oxford, UK, 2004.

46. Löhr, D. Das stumpfe Schwert der Bodenwertbesteuerung-Zugleich ein Plädoyer für das Erbbaurecht. Z Sozialökon. 2006, 43, 11-19.

47. Mankiw, N.G.; Taylor, M.P. Economics; Cengage Learning Ltd.: Andover; Hampshire, UK, 2006. 
48. Warner, T. Die deutsche Land-und Steuerordnung von Tsingtau und ihr Weiterwirken auf China. Z Sozialökon. 1999, 36, 15-18.

49. Perkins, D.H. China's Land System: Past, Present and Future. In Property Rights and Land Policies; Ingram, G.K., Hong, Y.H., Eds.; Lincoln Institute of Land Policy: Cambridge, MA, USA, 2009; pp. 70-95.

50. Krumm, R. Die Baulandausweisungsumlage als ökonomisches Steuerungsinstrument einer nachhaltigen Flächenpolitik; IAW Discussion Papers; IAW: Tübingen, Germany, 2002.

51. Coase, R. The Problem of Social Cost. J. Law Econ. 1960, 3, 1-44.

52. Pejovich, S. The Economics of Property Rights: Towards a Theory of Comparative Systems; Kluwer Academic Publishers: Dordrecht, The Netherlands, 1990.

53. Dieterich, H. Bodenordnung und Bodenpolitik. In Kompendium der Wohnungswirtschaft, 4th ed.; Jenkis, H., Ed.; Oldenbourg-Verlag: Munich, Germany; Vienna, Austria, 2001; pp. 516-542.

54. Asia Regional Assessment for the FAO Voluntary Guidelines on Responsible Governance of Tenure of Land and Other Natural Resources; Food and Agriculture Organization of the United Nations (FAO): Hanoi, Vietnam, 2009; Available online: ftp://ftp.fao.org/docrep/fao/ 012/ak802e/ak802e00.pdf (accessed on 14 December 2009).

(C) 2010 by the authors; licensee MDPI, Basel, Switzerland. This article is an open-access article distributed under the terms and conditions of the Creative Commons Attribution license (http://creativecommons.org/licenses/by/3.0/). 